\title{
Intercontinental distributions of species of Cortinarius, subgenus Phlegmacium, associated with Populus in western North America
}

\author{
Authors: Cathy L. Cripps, Kare Liimatainen, Tuula \\ Niskanen, Bálint Dima, Richard F. Bishop, \& Joseph F. \\ Ammarati
}

This is a postprint of an article that originally appeared in Botany in October 2015.

Cripps, Cathy L., Kare Liimatainen, Tuula Niskanen, Balint Dima, Richard F. Bishop, and Joseph F. Ammarati. "Intercontinental distributions of species of Cortinarius, subgenus Phlegmacium, associated with Populus in western North America." Botany (October 2015). DOI: https://dx.doi.org/10.1139/cib-2015-0089. 


\title{
Intercontinental distributions of species of Cortinarius, subgenus Phlegmacium, associated with Populus in western North America
}

\author{
Cathy L. Cripps, Kare Liimatainen, Tuula Niskanen, Bálint Dima, Richard F. Bishop, and \\ Joseph F. Ammirati
}

\begin{abstract}
Three species of Cortinarius subg. Phlegmacium, Cortinarius argutus Fr. and Cortinarius hedyaromaticus C. Cripps \& O.K. Mill. (section Arguti stat. nov.) and Cortinarius talus Fr. (section Multiformes), are compared from western North America and Europe. Phylogenetic analysis of the ITS region shows that $C$. argutus and $C$. hedyaromaticus are separate, closely related species with rooting stipes. Cortinarius talus is a pale species with a bulbous stipe and a sweet odor similar to that of $C$. hedyaromaticus; $C$. argutus lacks this sweet odor. All three species have intercontinental distributions and are associated with deciduous trees, primarily Populus tremuloides Michx., Populus tremula L., but also Salix spp. This study highlights the importance of the study of type specimens and molecular analysis to stabilize the application of established names.
\end{abstract}

Key words: ITS, molecular systematics, taxonomy, Agaricales, Cortinariaceae, Salicales.

Résumé : Trois espèces de Cortinarius subg. Phlegmacium, Cortinarius argutus Fr. et Cortinarius hedyaromaticus C. Cripps \& O.K. Mill. (section Arguti stat. nov.) et Cortinarius talus Fr. (section Multiformes) de l'ouest de l'Amérique du Nord et d'Europe sont comparées. L'analyse phylogénétique de la région de l'espaceur transcrit interne montre que $C$. argutus et $C$. hedyaromaticus sont des espèces séparées étroitement reliées possédant des stipes d'enracinement. Cortinarius talus est une espèce pâle à stipe bulbeux et à odeur mielleuse, similaire à celle de C. hedyaromaticus; $C$. argutus est dépourvu de cette odeur mielleuse. Les trois espèces ont une distribution intercontinentale et sont associées aux arbres décidus, principalement Populus tremuloides Michx., Populus tremula L. et aussi Salix spp. Cette étude souligne l'importance de l'étude de spécimens types et de l'analyse moléculaire afin de stabiliser l'application de noms établis. [Traduit par la Rédaction]

Mots-clés : espaceur transcrit interne, systématique, taxonomie, Agaricales, Cortinariaceae, Salicales.

\section{Introduction}

A number of papers have treated one or more species of Cortinarius associated with Salix and (or) Populus in Europe and North America, including Lamoure 1977, 1978, Ammirati and Laursen 1982, Moser and McKnight 1987, Rehner et al. 1988, Kotilová-Kubičková et al. 1990, Moser 1993, Cripps and Miller 1994, Thorn and Malloch 1994, Arnolds and Kuyper 1995, Brandrud 1996a, Ortega et al. 1998, Matheny and Ammirati 2006, and Cripps and Horak 2008. While these and related publications provide a wealth of morphological, ecological, and geographical information for a large number of Cortinarius species, most of them do not include DNA sequences or a phylogeny of the species, which is now common practice in Cortinarius studies (e.g., Niskanen et al. 2012; Ammirati et al. 2013).

The geographical distribution of Cortinarius species is not well known. A number of Cortinarius species, however, are confirmed with molecular data to occur in both western North American and European conifer forests (Garnica et al. 2011; Harrower et al. 2011; Liimatainen et al. 2014). Also, some species associated with deciduous trees in hemiboreal to alpine zones have broad distributions; these include Cortinarius lucorum (Fr.) P. Karst. with Populus trichocarpa Torr. \& A.Gray ex Hook. in western North America and Populus tremula L. in northern Europe 
Fig. 1. Aspen habitat at Conboy Lake Wildlife Refuge, Washington.

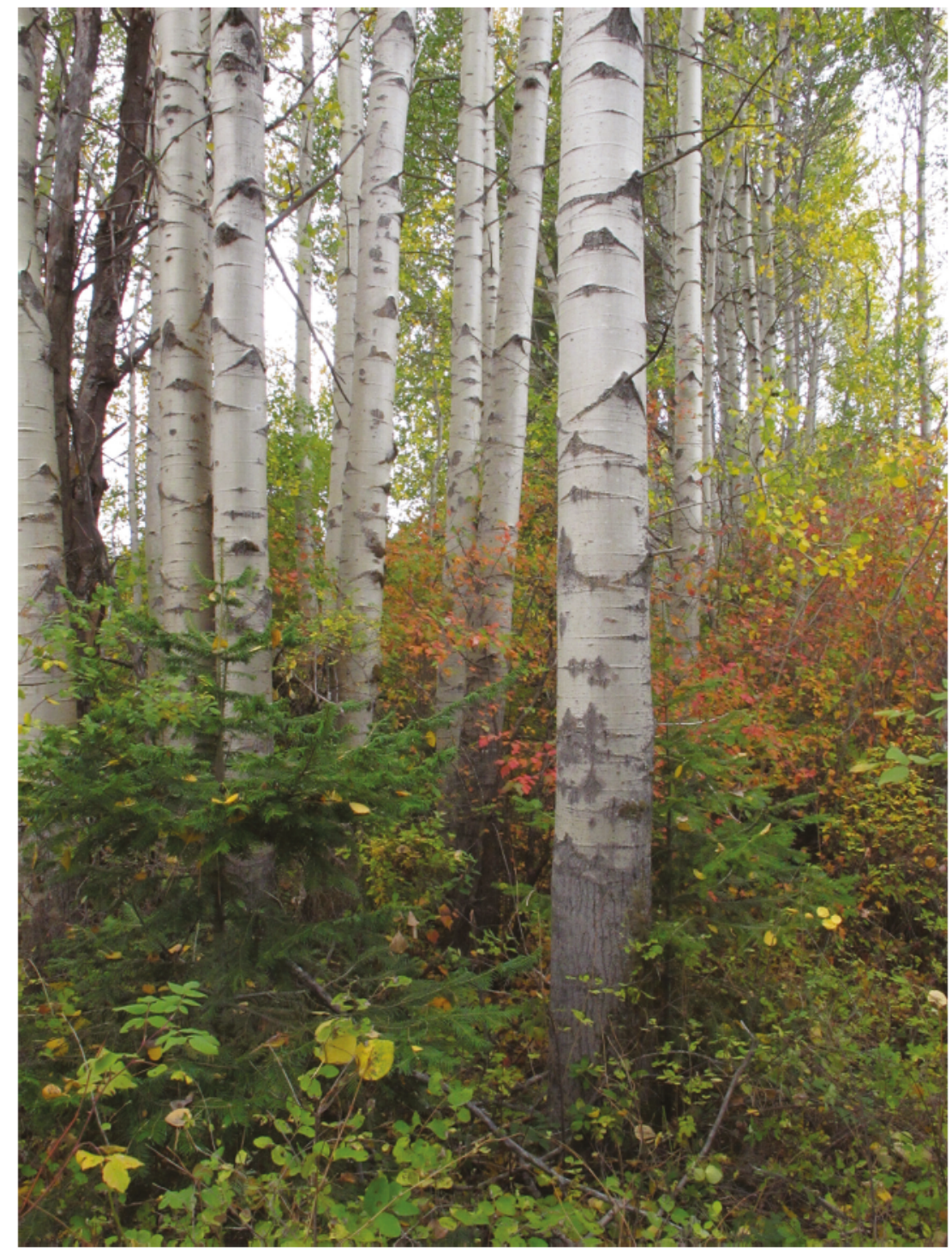

(Matheny and Ammirati 2006), Cortinarius armillatus (Fr.) Fr. with birch (Harrower et al. 2011), Cortinarius talus Fr. (Brandrud et al. 2014), and Cortinarius alpinus Boud. (= Cortinarius favrei D.M. Henderson) and Cortinarius absarokensis M.M. Moser \& McKnight with willow in arcticalpine and subalpine habitats (Peintner 2008). Several species of Inocybe with Salix from arctic-alpine habitats are molecularly confirmed to have broad intercontinental distributions as well (Cripps et al. 2010; Larsson et al. 2014).

A long standing problem associated with the identification of Cortinarius and other agaric species, has been the incorrect application of species names, compounded by the lack of a type collection for many early names. Recent publications, e.g., Niskanen et al. (2011), Ammirati et al. (2013), Liimatainen et al. (2014), combine the use of type studies and molecular phylogenies to stabilize the application of established names, identify new species, and infer evolutionary relationships among taxa.
In this paper, we examine three pale-colored species of Cortinarius in subgenus Phlegmacium: Cortinarius argutus Fr., Cortinarius hedyaromaticus C. Cripps \& O.K. Mill., and Cortinarius talus Fr. Previous molecular phylogenetic studies place C. talus in section Multiformes (Garnica et al. 2005, Liimatainen et al. 2014) and C. argutus in /Arguti (Garnica et al. 2005). Cortinarius hedyaromaticus was originally placed in section Phlegmacium, stirps Rapaceum (Cripps and Miller 1994), but Brandrud (1996a) placed it in subsection Arguti and considered it as a possible subspecies of $C$. argutus. All three species are here reported from aspen stands in Montana, USA. (Fig. 1). They are evaluated below on the basis of type collections and placed in a phylogenetic framework together with selected collections from North America and Europe.

\section{Materials and methods}

\section{Morphological studies}

Microscopic descriptions were made from sections of dried material mounted in $3 \% \mathrm{KOH}$ or fresh material 
mounted in water or $3 \% \mathrm{KOH}$. Basidiospores were mounted in Melzer's reagent to check for a dextrinoid reaction. Basidiospore measurements and $Q$ values are based on 20 spores from each of the collections listed as Specimens Examined. In all instances, basidiospore samples came from deposits on the stipe and (or) veil surface. Macrochemical reactions of fresh basidiomata were made with $3 \% \mathrm{KOH}$. General color notations were used for description of fresh specimens. The final descriptions of fresh basidiomata and microscopic features are based on an evaluation of multiple North American collections. European reference specimens are listed in the Supplementary Material ${ }^{1}$.

\section{Molecular analyses}

Collections used for sequencing the nuclear rDNA ITS1-5.8S-ITS2 region (internal transcribed spacer, ITS) and sequences retrieved from GenBank and UNITE are given in Table 1. DNA was extracted from dried material (pieces of lamellae) with the NucleoSpin Plant kit (Macherey-Nagel, Düren, Germany). Primers ITS1F and ITS4 (White et al. 1990; Gardes and Bruns 1993) were used to amplify most ITS regions and the same primer pairs were used in direct sequencing. Polymerase chain reaction amplification and sequencing followed Niskanen et al. (2009). Primers ITS1/ITS4 was used for Cortinarius rioussetiae Chevassut \& Rob. Henry and ITS1F/ITS4B for Cortinarius paracephalixus Bohus.

\section{Data analyses}

Sequences were assembled and edited with Sequencher 4.1 (Gene Codes, Ann Arbor, Michigan, USA). Using a BLAST query of the public databases (GenBank: http://www.ncbi. nlm.nih.gov/ and UNITE: http://unite.ut.ee/), we checked to see whether identical or similar sequences were in public databases. The ITS alignment of 58 sequences was produced with the program MUSCLE (Edgar 2004) under default settings. The alignment is composed of $630 \mathrm{nu}-$ cleotides (including gaps). The alignment is available at TreeBASE under S18067 (http://www.treebase.org/ treebase-web/home.html). Sequences were subjected to Maximum Likelihood (ML) analysis as implemented in RAxML version 8 (Stamatakis 2014) with 1000 bootstrap replicates under the GTRGAMMA model.

\section{Results of molecular studies}

The phylogenetic tree resulting from our RAxML analysis is shown in Fig. 2. All taxonomically treated species, C. argutus, $C$. hedyaromaticus, and $C$. talus, are well-defined based on their ITS sequences and form well-supported clades when bootstrap (BS) values were $>91 \%$ in our analysis. The intraspecific variation is very low, maximum of two base pairs (observed in C. argutus), and does not show any geographical or ecological structuring. Cortinarius argutus and $C$. hedyaromaticus form a strongly supported (BS = 92\%) subclade inside the section Arguti. All three species are shown to have an intercontinental distribution.

\section{Taxonomic studies}

Section Arguti (Brandrud \& Melot) Liimat., Ammirati, Niskanen, Dima \& C. Cripps stat. nov.

BASIONYM: Cortinarius subsect. Arguti Brandrud \& Melot in Nord. J. Bot. 10: 535 (1990).

TYPE OF THE SECTION: Cortinarius argutus Fr., Epicr. syst. mycol. (Upsaliae): 278 (1838) [1836-1838].

DIAGNOSIs: In Brandrud (1996a) and Bidaud et al. (1999), C. argutus is placed in the section Phlegmacium. The type species of this section is Cortinarius saginus (Fr.) Fr. The recent phylogenetic studies by Garnica et al. (2005) and Liimatainen et al. (2014) do not support a close relationship between $C$. saginus and $C$. argutus. Also, the relationships with morphologically somewhat similar species, i.e., Cortinarius triumphans s. auct. and Cortinarius vulpinus s. auct. were not supported. Furthermore, the /Arguti is wellsupported in the studies of Garnica et al. $(2005, \mathrm{BS}=100 \%)$ and in Liimatainen et al. (2014, Bayesian posterior probability $=0.98$ ) and is at the same level as many other accepted sections i.e., sect. Infracti, Scauri, Cyanites, etc. Although the phylogenetic relationships are inferred from ITS only, the previous study of Frøslev et al. (2005), in which the performance of ITS, rpb1, and rpb2 was compared, showed that relationships recovered by ITS with high nodal support ( $>65 \%$ bootstrap support and $>95 \%$ Bayesian posterior probability) are consistently supported in combined analyses.

The clade Arguti is also characterized by several morphological characteristics: basidiomata are pale, whitish to pale ochraceous, medium to large-sized. The stipe is more or less rooting. The spores are large $>9.5 \mu \mathrm{m}$ long, amygdaliform. The lamellar trama hyphae are often with dark granules in Melzer's reagent. The species are associated with coniferous and deciduous trees.

Based on the molecular and morphological data, we consider Arguti a well-delimited group and validate the name at section level. The section includes at least nine species in the northern Hemisphere: C. argutus, Cortinarius fraudulosus Britzelm., Cortinarius fraudulosoides Liimat. \& Niskanen, C. hedyaromaticus, C. paracephalixus, Cortinarius patrickensis (M.M. Moser) Niskanen, Liimat., Kytöv., Bojantchev \& Ammirati, C. rioussetiae, Cortinarius rosargutus Chevassut \& Rob. Henry, and Cortinarius subfraudulosus Kytöv., Liimat. \& Niskanen. Presumably, also Cortinarius herculeus Malençon belongs to this section, but the type material of the species has not yet been studied. Also, the phylogenetic relationships of Cortinarius populinus Brandrud remain to be studied. 
Table 1. Specimens and GenBank/Unite accession numbers of internal transcribed spacer (ITS) sequences used in the phylogenetic analysis.

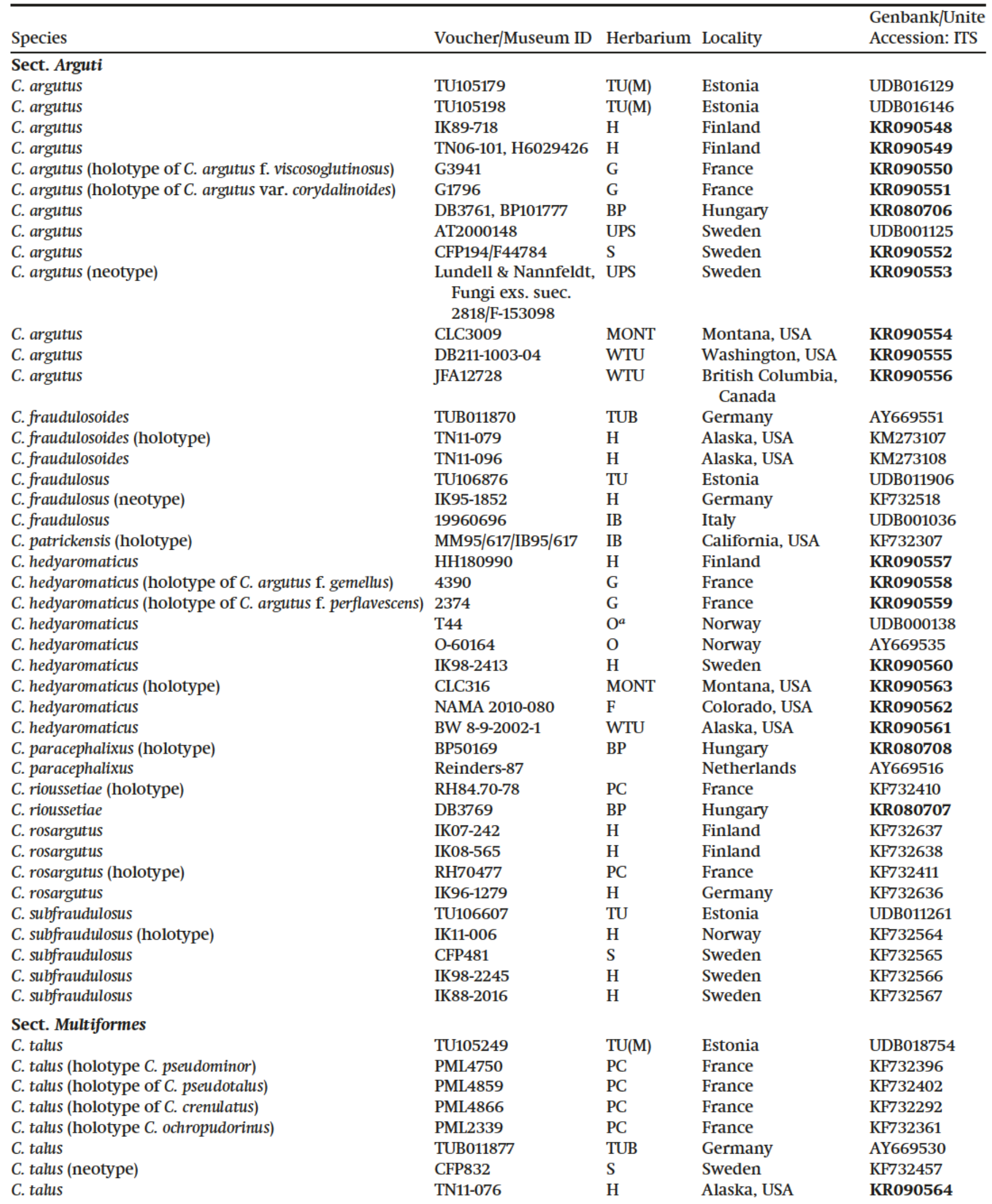


Table 1 (concluded).

\begin{tabular}{|c|c|c|c|c|}
\hline Species & Voucher/Museum ID & Herbarium & Locality & $\begin{array}{l}\text { Genbank/Unite } \\
\text { Accession: ITS }\end{array}$ \\
\hline C. talus & CLC467 & MONT & Montana, USA & KR090565 \\
\hline C. talus & CLC713 & MONT & Montana, USA & KR090566 \\
\hline C. talus & IB19910646 & IB & & AF389144 \\
\hline C. multiformis & TN07-244, H7000906 & $\mathrm{H}$ & $\begin{array}{l}\text { Newfoundland, } \\
\text { Canada }\end{array}$ & KR090567 \\
\hline C. multiformis (neotype) & CFP445 & $\mathrm{S}$ & Sweden & KF732350 \\
\hline C. multiformis & TN09-048 & $\mathrm{H}$ & Washington, USA & KR090569 \\
\hline
\end{tabular}

Note: Sequences produced in this study are indicated by boldface type. TU, University of Tartu, Herbarium; H, University of Helsinki, Finnish Museum of Natural History, Botanical Museum; G, Geneva Herbarium; UPS, Uppsala Natural History Museum; S, Swedish Museum of Natural History; WTU, University of Washington Herbarium; TUB, University of Tubingen, Herbarium; IB, University of Innsbruck Herbarium; MONT, Montana State University Herbarium; PC, National Museum of Natural History, Paris; TU(M), University of Tartu Herbarium/Culture collection; BP, Hungarian Natural History Museum; O, Botanical Museum of Oslo; F, Field Museum of Natural History, USA.

${ }^{a}$ Location uncertain at publication.

Descriptions are all based on North American material.

Cortinarius argutus Fr., Epicr. syst. mycol. (Upsaliae): 278 (1838) [1836-1838]

Figs. 3, 4

= Cortinarius argutus f. viscosoghutinosus Bidaud, MoënneLocc. \& Reumaux, in Bidaud et al., Atlas des Cortinaires 10: 370 (1999) [2000]

= Cortinarius argutus var. corydalinoides Langl. \& Reumaux, in Bidaud et al., Atlas des Cortinaires 10: 370 (1999) [2000] DESCRIPTION: Pileus: 3-10 cm diameter, convex to plane, margin slightly incurved to decurved, margin at first covered or fringed with whitish veil, becoming uplifted to undulate; surface smooth becoming slightly rimose on disc, lubricous to viscid becoming dry; color white, off white, cream to buff (with slight orange buff tones) or pale yellowish brown to light dull yellow, disc sometimes becoming orangish light brown; surface of young pilei stain yellow when cut or bruised. Lamellae: adnexed to notched, somewhat broad, close to crowded, color white to pinkish cream at first (reported as pale purple in the description of $C$. argutus f. viscosoglutinosus but otherwise not observed), becoming yellowish white, pale dull yellow, brownish yellow, or milk coffee; edges even, paler in color. Veil white, sometimes copious on young specimen, forming a distinct fringe on the edge of young pilei, ephemeral, leaving fibrils on the stipe; cortina whitish. Stipe: $5-11.5 \mathrm{~cm}$ long, $0.8-3 \mathrm{~cm}$ thick above, long, narrow, flared at apex, base $1-1.2 \mathrm{~cm}$ thick, slightly swollen tapering to a dull point (slightly rooting); white to cream, sometimes becoming brownish, reddish brown or light purplish; lower surface with sparse fibrils from veil. Context white, sometimes slightly yellowish when bruised, solid, firm, fibrous (woody) in stipe base. Odor: faint, mildly unpleasant, raphanoid or nauseous.

KOH Reaction: Fresh material - negative on pileus surface.

Exsiccatae: Pileus and stipe pale buff, with upper stipe and flesh bluish to grayish.
Basidiospores: $10-11(-12) \mu \mathrm{m} \times 5-6 \mu \mathrm{m}$, on average $10.4 \mu \mathrm{m} \times 5.2 \mu \mathrm{m}, Q=2.0$ (1.99), amygdaliform to narrowly amygdaliform, moderate to distinctly verrucose, not or slightly dextrinoid. Lamella edge fertile. Pileipellis with a very thin gelatinous layer, a rather narrow but distinct epicutis, and a well-defined hypocutis, the latter two layers yellow-pigmented. Tissue mounted in Melzer's reagent turning very dark brown due to the formation of black globules in the hyphae. Clamp connections present.

HABITAT: Scattered to gregarious or more commonly caespitose in aspen (Populus tremuloides) stands with tall grasses, in mixed stands of aspen and conifers (pine, Douglas fir, true fir, and (or) spruce) and sometimes with admixture of birch or shrubs (rose, hawthorn, willow, alder, spirea); also reported once with Salix. In Europe with Populus tremula often on clay soil.

SPECimENS EXAMinED: Canada. British Columbia, Victoria, Lake Masachi under willows, 30 November 1999, leg. Paul Kroeger, JFA12728 (WTU). USA. Montana. Gallatin County: Bozeman, Sourdough Creek under aspen, 14 September 2013, leg. C. Cripps, CLC 3009 (MONT). Washington. Klickitat County: Conboy Lake Wildlife Refuge, near intersection of Laurel Road and Kreps Lane under aspen, 3 October 2011, leg. D. Bishop \& S.T. Jones, DB211-1003-04 (WTU), loc. cit., 14 October 2011, leg. D. Bishop \& S.T. Jones, DB211-1014-01 (WTU).

OBSERVATIONS: Cortinarius argutus has rarely been reported from western North America even though it can be identified in the field due to its whitish coloration and association with Populus species, especially aspen; although we now know it can be confused with $C$. hedyaromaticus. It appears to be a rather widespread species found in Europe and North America in mountainous and boreal regions, including the edges of forests and parks. One collection of C. argutus was found under Salix (JFA12728, WTU); it matches closely the morphological and microscopic description of collections from aspen stands. 
Fig. 2. Phylogenetic tree inferred from internal transcribed spacer regions. Bootstrap values $>50 \%$ are indicated above branches. C. arg., Cortinarius argutus; C. hedyarom., Cortinarius hedyaromaticus; C. arg. f. perflav., Cortinarius argutus f. perflavescens.

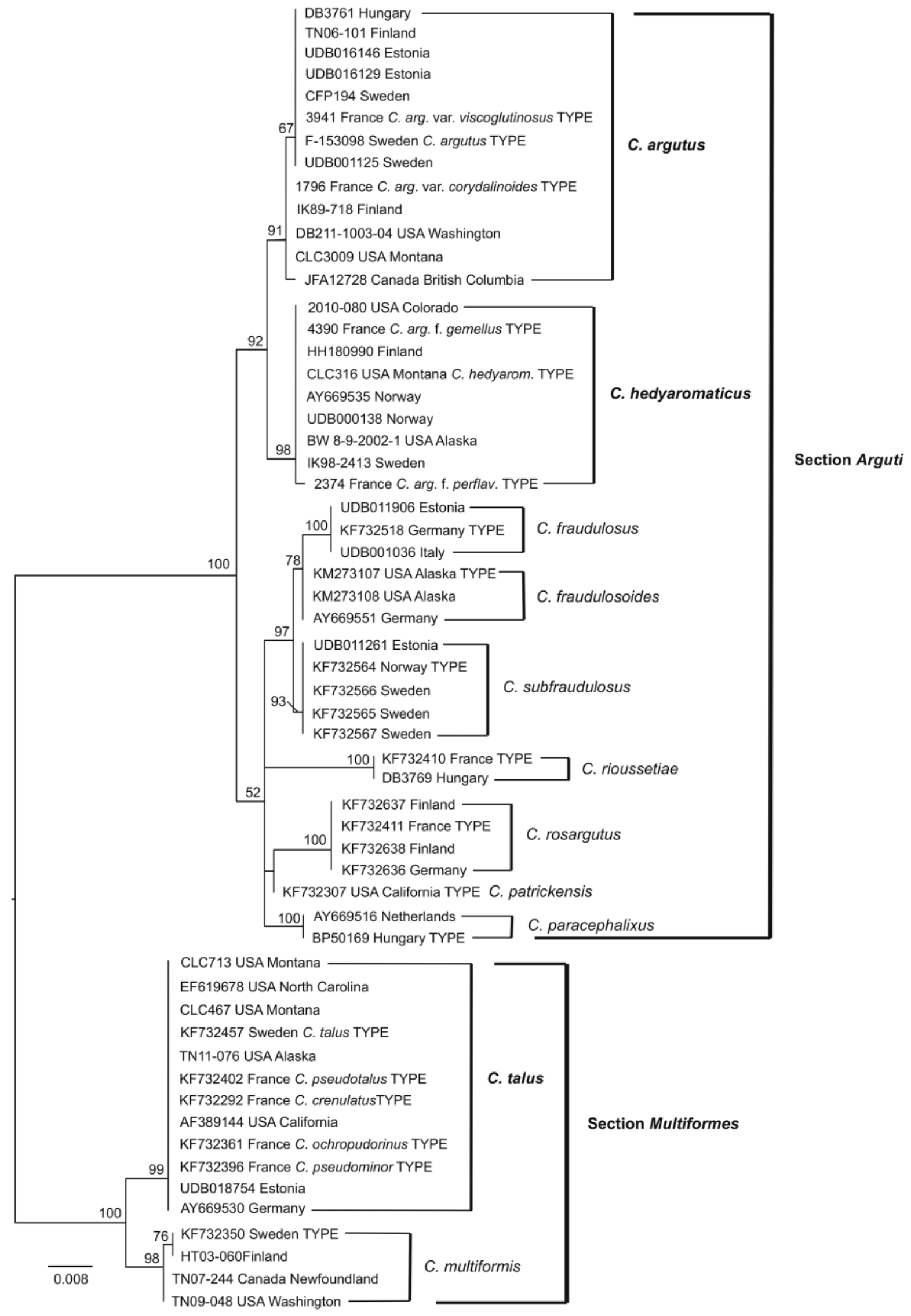


Fig. 3. North American material. Top row: Cortinarius argutus DB211-1003-04 and CLC 3009. Middle row: C. hedyaromaticus NAMA 2010-080 and CLC 316 (Holotype). Bottom row: C. talus CLC 713 and CLC 467.
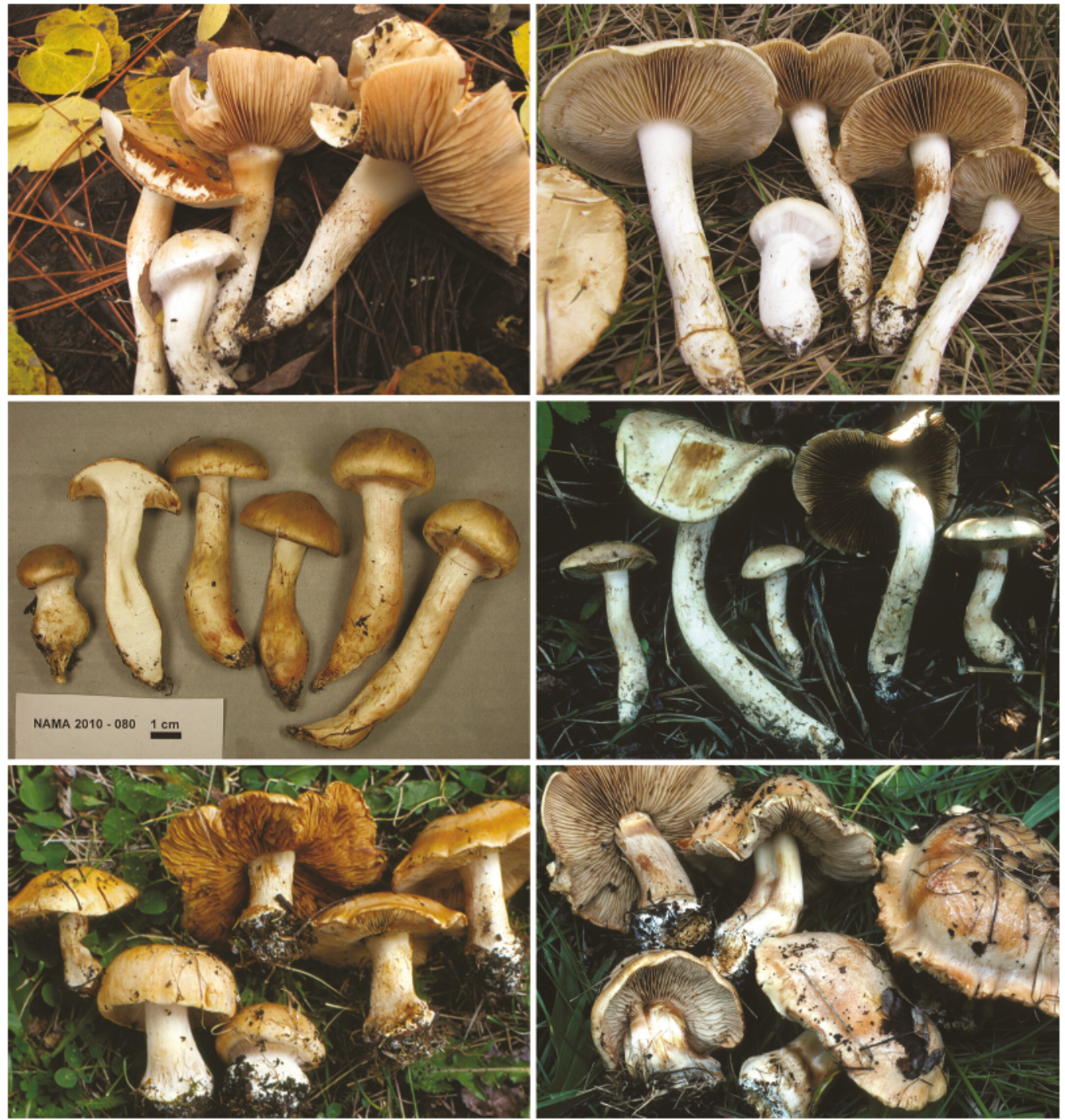

Fig. 4. Spores. (Left panel) Cortinarius argutus CLC 3009, (middle panel) Cortinarius hedyaromaticus CLC 316, (right panel) Cortinarius talus CLC 467. Scale bars $=10 \mu \mathrm{m}$.
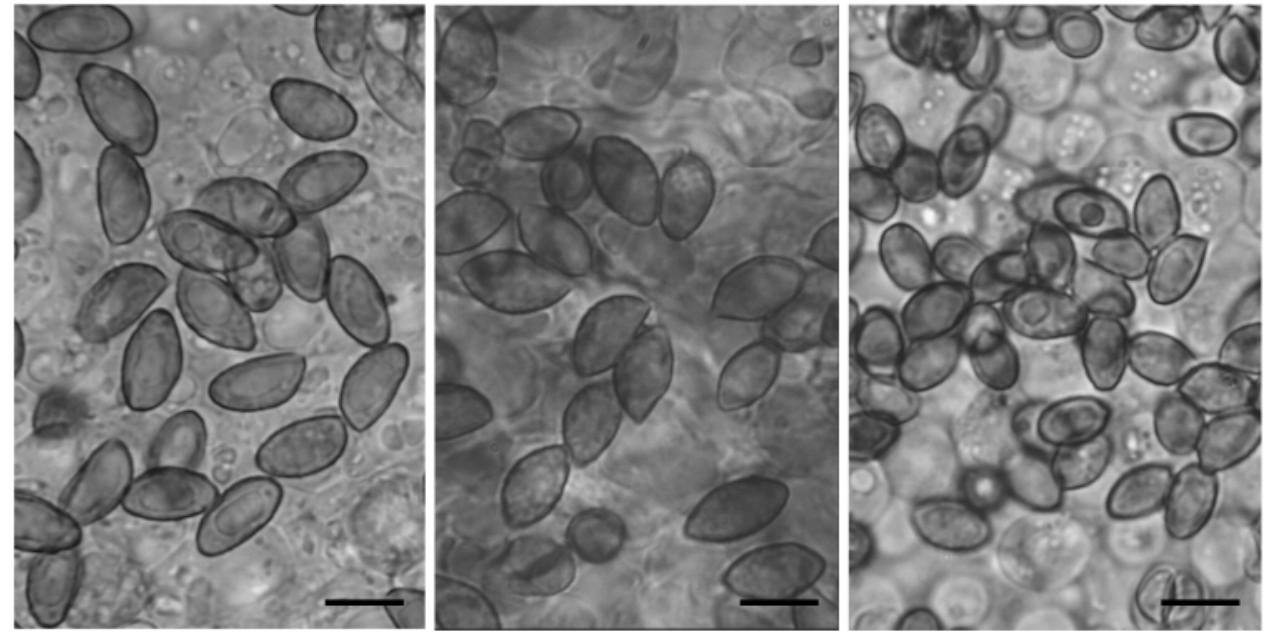
Spores of CLC 3009 were slightly different in size, 8.910.4(-11.1) $\mu \mathrm{m} \times 5.2-5.8(-6.7) \mu \mathrm{m}$.

Cortinarius argutus belongs to section Arguti and is a sister species to $C$. hedyaromaticus (differs from it by five substitutions and two indel positions in the ITS regions). Cortinarius hedyaromaticus is also pale with a slightly rooting stipe base, but it has a strong sweet odor and the stipe apex is not consistently bluish in exsiccate examined, although it has dark globules in Melzer's (see Brandrud $1996 b$ for more details on color reactions).

\section{Cortinarius hedyaromaticus C. Cripps \& O.K. Mill., Myco- taxon 50: 316 (1994)}

Figs. 3, 4.

HOLOTYPE: USA. Montana, Park County, Cinnabar Basin under aspen with conifers a distance away, 28 August 1991, C. Cripps, CLC 316 (MONT). GenBank No. KR090563.

$=$ Cortinarius argutus f. gemellus Bidaud, Moënne-Locc. \& Reumaux, in Bidaud et al., Atlas des Cortinaires 10: 370 (1999) [2000]

= Cortinarius argutus $\mathrm{f}$. perflavescens Bidaud, MoënneLocc. \& Reumaux, in Bidaud et al., Atlas des Cortinaires 10: 370 (1999) [2000]

DESCRIPTION: Pileus: $7-9(-15) \mathrm{cm}$ in diameter, at first hemispherical with strongly inrolled margin, becoming broadly convex; surface smooth or rimose-areolate on the disc, lubricous becoming dry; cream buff (whitish) or pinkish buff at first, more buff in some areas, bruising a rusty color towards margin, maturing to light brown and remaining so when dried, sometimes with localized areas of steel blue gray tones in age; edge occasionally fringed with whitish membranous veil when young. Lamellae: subdecurrent, crowded, medium broad, pale buff to clay color, becoming light cocoa, then brown or grayish brown; edges bruising vinaceous brown or steel gray. Stipe: extremely variable in length, 7-11 cm long, $1-2.5 \mathrm{~cm}$ wide above, equal or enlarging somewhat towards the base, and then tapered to a point (rooting), smoothfibrous, whitish cream at first with a few scattered rusty fibrils, with a few pale yellow areas; apex sometimes with steel gray areas above the superior annulus zone when mature. Veil nearly membranous, ephemeral; cortina whitish, leaving a superior zone of fibrils on stipe that becomes brown from deposited spores. Context firm, especially in the stipe, white, sometimes staining brownish or vinaceous at the stipe apex or base. Odor: strong, sweet like vanilla cake batter, then sickeningly sweet on drying. Taste: not recorded.

KOH Reaction: Fresh material - pileus surface pale yellow in $3 \% \mathrm{KOH}$.

Exsiccatae: Pileus and stipe buff, lamellae more reddish brown, slight reddish brown staining, no bluish coloration in specimens examined but stored specimens are grayish in places. However, microscopically dark globules are present in Melzer's as for section Arguti in general.
Basidiospores: 9.6-11.1(-12.2) $\mu \mathrm{m} \times 5.2-5.9(-7) \mu \mathrm{m}$, on average $10.4 \mu \mathrm{m} \times 6.0 \mu \mathrm{m}, Q$ on average 1.7 , amygdaliform to narrowly amygdaliform, moderately verrucose, not dextrinoid. Pileipellis composed of a thin gelatinous layer, with a moderately developed, yellowish epicutis and broad, golden yellow to orangish yellow hypocutis. Tissue mounted in Melzer's reagent turning very dark brown due to the formation of black globules in the hyphae. Clamp connections present.

навітAт: Terrestrial, scattered, caespitose or in a ring, beneath aspen (Populus tremuloides), in the Rocky Mountains, USA. In Europe, with P. tremula or in mixed forests including P. tremula.

SPECIMENS EXAMINED: USA. Alaska. Kenai Peninsula: Skilak Lake Road, Skilak Lake, 9 August 2002, leg. Ben Woo, BW8-9-2002-1 (WTU). Colorado. Grand County, Granby, Snow Mountain Ranch under aspen, 12 August 2010, leg. H. Sila, M. Bishop, O. Barizo, NAMA 2010-080 (F). Montana. Park County, Cinnabar Basin under aspen with conifers a distance away, 11 August 1991, leg. C. Cripps, CLC 260 (MONT), loc. cit., 28 August 1991, leg. C. Cripps, CLC 316 (MONT, holotype, NY, isotype).

oBSERVATIONS: In addition to the type locality (Montana), C. hedyaromaticus is confirmed from Colorado and Alaska in western North America and is considered a rare species in this region to date. In Europe the species is known from Norway, Sweden, and Finland, as well as France. See comments under $C$. argutus for morphological differences.

Section Multiformes Rob. Henry ex. Moënne-Locc. \& Reumaux

Cortinarius talus Fr. Epicr. syst. mycol. (Upsaliae): 263 (1838) [1836-1838]

Figs. 3, 4.

= Cortinarius aurantionapus Bidaud \& Reumaux, in Bidaud et al., Atlas des Cortinaires 16: 1096 (2006)

$=$ Cortinarius crenulatus Rob. Henry ex Bidaud \& Reumaux, in Bidaud et al., Atlas des Cortinaires 16: 1097 (2006)

= Cortinarius ochropudorinus Rob. Henry ex Bidaud \& Reumaux, in Bidaud et al., Atlas des Cortinaires 16: 1097 (2006)

= Cortinarius pseudominor Rob. Henry ex Reumaux, in Bidaud et al., Atlas des Cortinaires 16: 1098. (2006)

$=$ Cortinarius pseudotalus Rob. Henry ex Bidaud \& Reumaux, in Bidaud et al., Atlas des Cortinaires 16: 1098. (2006)

DESCRIPTION: Pileus: $10-12 \mathrm{~cm}$ in diameter, convex, often broadly umbonate, margin decurved becoming uplifted to undulate uplifted; surface smooth, very viscid, dries to a sheen, light yellow buff or cream buff, mottled and marbled with a whitish viscid sheen from veil over the cream buff ground color. Lamellae: sinuate sometimes with decurrent lines, crowded, broad, to $1 \mathrm{~cm}$ wide, pale grayish cream, pale orangish brown, with somewhat 
darker spots at maturity or on bruising, later red brown; edges darker brown, slightly crenate. Cortina not observed, but sparse, whitish fibrils present on stipe surface. Stipe: $5-8 \mathrm{~cm}$ long, $1.8-3 \mathrm{~cm}$ wide above, 3.5 to $4.5 \mathrm{~cm}$ wide at base, equal down to the somewhat abrupt wide bulbous base, smooth-fibrous, mostly ocher cream, but staining/bruising reddish brown on the lower surface; basal mycelium white. Context white or ocher especially in the base, tissue layer above the lamellae translucent. Odor: strong, sweet, honey-like. Taste: at least in CLC 713 mild.

Exsiccatae: Pileus, lamellae, stipe and context strongly reddish brown.

Basidiospores: $7-8.4 \mu \mathrm{m} \times 4.5-5.4 \mu \mathrm{m}$, average $7.65 \mu \mathrm{m} \times 4.92 \mu \mathrm{m}$, average $Q=1.67$, amygdaloid to ellipsoid, with fine verruculae, not or only slightly dextrinoid. Lamella edges fertile. Pileipellis very distinctive; surface layer of well-developed gelatinous hyphae, epicutis a rather narrow zone, hypocutis distinct, broad, brown pigmented. Black globules absent when tissue is mounted in Melzer's reagent. Clamp connections present.

навітAт: In groups under mature aspen (P. tremuloides) in southwestern Montana in summer and reported from a conifer forest that includes aspen and birch in Alaska. In Europe considered to be associated with Betula, Carpinus, Corylus, Fagus, and Quercus (Jeppesen et al. 2012; Brandrud et al. 2014); mostly reported from deciduous or mixed forests, some with Populus.

SPECIMENS EXAMINED: USA. Alaska. Fairbanks, conifer dominated forest with some Betula and Populus, 15 August 2011, leg. K. Liimatainen \& T. Niskanen, 11-076 (H). Montana. Park County, Cinnabar Basin, almost pure aspen forest with one conifer nearby, 13 July 1993, CLC 467 (MONT), leg. C. Cripps, loc. cit., 17 August 1993, leg. C. Cripps, CLC 713 (MONT).

REFERENCE SPECIMENS SEQUENCED FROM NORTH AMERICA: GenBank: USA. California, IB19910646 (IB). GenBank No. AF389144. North Carolina. Orange Co, Pinus taeda dominated forest. GenBank No. EF619678.

OBSERVATIONS: This is a widespread intercontinental species but host delineation is more difficult because the ecological information is rather diffuse for most collections. The North American collections from Montana are from an almost pure aspen stand, but occasional conifers are present. In Europe the species is reported to grow with several deciduous tree species (e.g., Quercus, Fagus, and Betula), but the possible association with Populus cannot be excluded. The neotype is from a mixed Betula, Populus, and Pinus forest.

Cortinarius talus is pale when young and, like C. hedyaromaticus, it typically has a strong, sweet odor. However, in contrast with species of section Arguti, the stipe base is bulbous, not rooting, exsiccate are rusty reddish without bluish or grayish tones, spores are smaller than for the other two species, and the lamellar trama hyphae lack dark globules in Melzer's reagent. The spores measured from the North American specimens were under $8.5 \mu \mathrm{m}$ long, similar in size to those of $C$. talus specimens collected from Northern European Betula pubescens forests (Brandrud et al. 2014).

\section{Discussion}

Nomenclature and type studies

For 20 years, $C$. hedyaromaticus was an enigmatic species, only known from the type locality in Montana. In Europe, the species was confused with C. argutus. Brandrud (1996a) in his revision of section Phlegmacium, proposed that it should probably be treated as a subspecies of $C$. argutus. Bidaud et al. (1999) described a forma and a variety of C. argutus which turned out to be $C$. hedyaromaticus. Also, Garnica et al. (2005) and Klaus Høiland each deposited a sequence of $C$. hedyaromaticus in GenBank/UNITE under the name C. argutus (AY669535, UDB000138). Only the studies of type specimens of $C$. argutus and $C$. hedyaromaticus combined with a larger study of material from both species revealed that each has a wide distribution in north temperate forests.

This study emphasizes the importance of molecular studies of taxa (including types) with similar ecological and morphological characteristics. Without these studies, the distinction between these two species is difficult to resolve across a broad geographical region spanning two continents. ITS sequences of type specimens are essential for a reliable identification and a barcoding database because semi-cryptic and phylogenetic species cannot be distinguished on morphology alone. The importance of type studies was also emphasized in the recent papers by Schoch et al. (2014) and Liimatainen et al. (2014).

European names have been used in North America for Cortinarius species, but North American names rarely have been used in Europe. Also, many names described after the 1980s have not been considered equally amongst mycologists (a majority of widespread names are those of Fries, and others). Because some of the species occur in North America and Europe, types from both areas should be studied and sequenced. This has been largely neglected in earlier Cortinarius studies but more recently, e.g., Moser and Peintner (2002), Garnica et al. (2009), and Liimatainen et al. (2014) have included North American type material in their studies.

\section{Ecology and distribution}

Aspen forests in Europe and North America are depauperate in Phlegmacium species. In Montana, all three species, C. argutus, C. hedyaromaticus, and $C$. talus, occur in association with Populus or in mixed stands containing Populus. In other areas, C. argutus and C. hedyaromaticus are also reported with aspen and $C$. argutus is reported once here with Salix in British Columbia, Canada. Cortinarius talus is relatively more frequent and has a broader range of hosts including members of the 
Fagaceae, Salicaceae, and Betulaceae. In boreal areas C. talus grows in association with Betula and at least in North America with Populus, but in hemiboreal and temperate areas it is also found with Quercus and Fagus.

Except for the sole Salix report from Canada, C. argutus and $C$. hedyaromaticus appear to be strict Populus associates across the Northern hemisphere. Moreover, additional strict Populus associates occur in the clade Arguti: C. paracephalixus and $C$. rioussetiae.

All three species described have a wide distribution extending from western North America to Europe and presumably are circumboreal. This supports the earlier observations that at least some Cortinarius species associated with deciduous trees in hemiboreal-alpine zones may have a wide distribution. It may be that many species are widely distributed across these habitats but currently what percentage is not known.

However, molecular analysis of Tricholoma populinum J.E. Lange, a species restricted to various Populus species, revealed a strongly supported, but recent, intercontinental lineage divergence for populations in Scandinavia and North America coincident with speciation of Populus hosts P. tremula and Populus balsamifera (Grubisha et al. 2012).

\section{Acknowledgements}

This study was supported in part by the D.E. Stuntz Memorial Foundation, the Academy of Finland (Project No. 129052), and Oskar Öflunds Stiftelse. We thank Tor Erik Brandrud for his help with identification of Phlegmacium species. We gratefully acknowledge Ibai Olariaga and Stefan Ekman (both Museum of Evolution, University of Uppsala) and Gizella Vasas (Hungarian Natural History Museum) for managing the loans of the type specimens of C. argutus and $C$. paracephalixus, respectively. We also thank Diána Seress and Gábor M. Kovács (Eötvös Loránd University, Budapest) for helping in the sequencing of the holotype of C. paracephalixus, and Ed Barge (Montana State University) for sequencing several North American specimens.

\section{References}

Ammirati, J.F., and Laursen, G.A. (Editors). 1982. Cortinarii in Alaskan arctic tundra. In Arctic and Alpine Mycology, the First International Symposium on Arcto-Alpine Mycology. University of Washington Press, Seattle, Wash. pp. 282-315.

Ammirati, J.F., Hughes, K.W., Liimatainen, K., Niskanen, T., and Matheny, P.B. 2013. Cortinarius hesleri from eastern North America and related species from Europe and western North America. Botany, 91(2): 91-98. doi:10.1139/cjb-2012-0154.

Arnolds, E., and Kuyper, T.W. 1995. Cortinarius species associated with Salix repens in the Netherlands. Beih. Sydowia, 8: 5-27.

Bidaud, A., Moënne-Loccoz, P., and Reumaux, P. 1999. Atlas des Cortinaires Pars IX(1), Sous genre Phlegmacium, section Phlegmacium. Èditions Fèdération mycologique DauphinéSavoie, France.

Brandrud, T.E. 1996a. Cortinarius subgenus Phlegmacium section Phlegmacium in Europe: Descriptive part. Edinb. J. Bot. 53: 331-400. doi:10.1017/S0960428600003772.
Brandrud, T.E. 1996b. Cortinarius, subgenus Phlegmacium, section Phlegmacium in Europe. A study of character variation and ecology including a numerical analysis of the C. argutus complex. Mycol. Res. 100(4): 471-485. doi:10.1016/S0953-7562(96) 80146-8.

Brandrud, T.E., Dima, B., Schmidt-Stohn, G., Bellù, F., Frøslev, T.G., Oertel, B., Saar, G., and Soop, K. 2014. Cortinarius subgenus Phlegmacium section Multiformes in Europe. J.J.E.C. 16: 162-199.

Cripps, C.L., and Horak, E. 2008. Checklist and ecology of the Agaricales, Russulales and Boletales in the alpine zone of the Rocky Mountains (Colorado, Montana, Wyoming) at 3000$4000 \mathrm{~m}$ a.s.l. Sommerfeltia, 31: 101-123. doi:10.2478/v10208011-0005-5.

Cripps, C.L., and Miller, O.K., Jr. 1994. A new Cortinarius from a mature aspen stand in Montana. Mycotaxon, 50: 315-321.

Cripps, C.L., Larsson, E., and Horak, E. 2010. Subgenus Mallocybe (Inocybe) in the Rocky Mountain alpine zone. N. Am. Fungi, 5(5): 97-126. doi:10.2509/naf2010.005.0057.

Edgar, R.C. 2004. MUSCLE: multiple sequence alignment with high accuracy and high throughput. Nucleic Acids Res. 32: 1792-1797. doi:10.1093/nar/gkh340. PMID:15034147.

Frøslev, T.G., Matheny, P.B., and Hibbett, D.S. 2005. Lower level relationships in the mushroom genus Cortinarius (Basidiomycota, Agaricales): a comparison of RPB1, RPB2, and ITS phylogenies. Mol. Phylogenet. Evol. 37: 602-618. doi:10.1016/j. ympev.2005.06.016. PMID:16085431.

Gardes, M., and Bruns, T.D. 1993. ITS primers with enhanced specificity for basidiomycetes. Application to the identification of mycorrhizae and rusts. Mol. Ecol. 2: 113-118. doi:10. 1111/j.1365-294X.1993.tb00005.x. PMID:8180733.

Garnica, S., Weiß, M., Oertel, B., and Oberwinkler, F. 2005. A framework for a phylogenetic classification in the genus Cortinarius (Basidiomycota, Agaricales) derived from morphological and molecular data. Can. J. Bot. 83(11): 1457-1477. doi: 10.1139/b05-107.

Garnica, S., Weiß, M., Oertel, B., Ammirati, J., and Oberwinkler, F. 2009. Phylogenetic relationships in Cortinarusu, section Calochroi, inferred from nuclear DNA sequences. BMC Evol. Biol. 9: 1. doi:10.1186/1471-2148-9-1. PMID:19121213.

Garnica, S., Spahn, P., Oertel, B., Ammirati, J., and Oberwinkler, F. 2011. Tracking the evolutionary history of Cortinarius species in section Calochroi, with transoceanic disjunct distributions. BMC Evol. Biol. 11: 213. doi:10.1186/14712148-11-213. PMID:21771336.

Grubisha, L., Levsen, N., Olson, M., and Taylor, L. 2012. Intercontinental divergence in the Populus-associated ectomycorrhizal fungus, Tricholoma populinum. New Phytol. 194: 548-560. doi:10.1111/j.1469-8137.2012.04066.x. PMID:22332931.

Harrower, E., Ammirati, J.F., Cappuccino, A.A., Ceska, O., Kranabetter, J.M., Kroeger, P., Lim, S., Taylor, T., and Berbee, M.L. 2011. Cortinarius species diversity in British Columbia and molecular phylogenetic comparison with European specimen sequences. Botany, 89(11): 799-810. doi:10. 1139/b11-065.

Jeppesen, T.S., Frøslev, T.G. and Brandrud, T.E. 2012. Subgen. Phlegmacium (Fr.) Trog. In Funga Nordica. 2nd revised ed. Agaricoid, boletoid, clavarioid, cyphelloid and gastroid genera. Edited by H. Knudsen and J. Vesterholt. Nordsvamp, Copenhagen, Denmark. pp. 782-826.

Kotilová-Kubičková, L., Ondok, J.P., and Přibáň, K. 1990. Phenology and growth of Dermocybe uliginosa in a willow carr. I. Phenology of fruiting. Mycol. Res. 94: 762-768. doi:10.1016/S09537562(09)81376-2.

Lamoure, D. 1977. Agaricales de la zone alpine. Genre Cortinarius Fr. sous-genre Telamomia (Fr.) Loud, $1^{\text {er }}$ Partie. Travaux Scientifiques du Parc National de la Vanoise, VII: 115-146.

Lamoure, D. 1978. Agaricales de la zone alpine. Genre Cortinarius 
Fr. sous-genre Telamonia (Fr.) Loud. Travaux Scientifiques du Parc National de la Vanoise, IX: 77-101.

Larsson, E., Vauras, J., and Cripps, C.L. 2014. Inocybe leiocephala, a species with an intercontinental distribution rangedisentangling the I. leiocephala-subbrunnea-catalaunica morphological species complex. Karstenia, 54: 15-39.

Liimatainen, K., Niskanen, T., Dima, B., Kytövuori, I., Ammirati, J.F., and Frøslev, T.G. 2014. The largest type study of Agaricales species to date: bringing identification and nomenclature of Phlegmacium (Cortinarius, Agaricales) into the DNA era. Persoonia, 33: 98-140. doi:10.3767/003158514X684681. PMID:25737596.

Matheny, P.B., and Ammirati, J.F. 2006. Cortinarius lucorum (Fr.) Karst, a Populus associate from North America. Pac. Northw. Fungi, 1(4): 1-10. doi:10.2509/pnwf.2006.001.004.

Moser, M. 1993. Studies on North American Cortinarii. III. The Cortinarius flora of dwarf and shrubby Salix associations in alpine zone of the Windriver Mountains, Wyoming, U.S.A. Sydowia, 45: 275-306.

Moser, M., and McKnight, K. 1987. Fungi (Agaricales, Russulales) from the Alpine Zone of Yellowstone National Park and the Beartooth Mountains with Special Emphasis on Cortinarius. Arctic Alpine Mycol. II Environ. Sci. Res. 34: 299-317. doi:10. 1007/978-1-4757-1939-0_20.

Moser, M., and Peintner, U. 2002. Die phylogenetischen Beziehungen der Cortinarius aureopulverulentus-Gruppe. J.J.E.C. 4: 28-38.

Niskanen, T., Kytövuori, I., and Liimatainen, K. 2009. Cortinarius sect. Brunnei (Basidiomycota, Agaricales) in North Europe. Mycol. Res. 113: 182-206. doi:10.1016/j.mycres.2008.10.006. PMID:19027854.

Niskanen, T., Kytövuori, I., and Liimatainen, K. 2011. Cortinarius sect. Armillati in northern Europe. Mycologia, 103: 1080-1101. doi:10.3852/10-350.
Niskanen, T., Liimatainen, K., Kytövuori, I., and Ammirati, J.F. 2012. New Cortinarius species from conifer-dominated forests of North America and Europe. Botany, 90(8): 743-754. doi:10. 1139/b2012-038.

Ortega, A., Mahiques, R., and Bidaud, A. 1998. Contribucion al estudio del genero Cortinarius en España peninsular. III parte: Algunas especies interesantes del subgénero Telamonia. Crytogamie Mycol. 19(3): 207-225.

Peintner, U. 2008. Cortinarius alpinus as an example for morphological and phylogenetic species concepts in ectomycorrhizal fungi. Sommerfeltia, 31: 161-177. doi:10.2478/v10208-0110009-1.

Rehner, S.A., Ammirati, J.F., and Mueller, G.J. 1988. Cortinarius stuntzii sp. nov. (Agaricales, Cortinariaceae), from Salix communities in eastern Washington. Mycologia, 80: 903-906. doi: $10.2307 / 3807581$.

Schoch, C., Robbertse, B., Robert, V., Vu, D., Cardinali, G., Irinyi, L., et al. 2014. Finding needles in haystacks: linking scientific names, reference specimens and molecular data for Fungi. Database, 2014: article ID bau061. doi:10.1093/ database/bau061.

Stamatakis, A. 2014. RAxML Version 8: a tool for phylogenetic analysis and post-analysis of large phylogenies. Bioinformatics, 30(9): 1312-1313. doi:10.1093/bioinformatics/btu033. PMID: 24451623.

Thorn, R.G., and Malloch, D.W. 1994. Species of Cortinarius subspecies Leprocybe, sections Orellani and Limonei, in North America. Can. J. Bot. 72(4): 520-532. doi:10.1139/b94-070.

White, T.J., Bruns, T., Lee, S., and Taylor, J. 1990. Amplification and direct sequencing of fungal ribosomal RNA genes for phylogenetics. In PCR protocols: a guide to the methods and applications. Edited by A.J. Michael, D.H. Gelfand, J.J. Sninsky, and T.J. White. Academic Press, New York. pp. 315-322. 